\title{
ЗМІНИ ПОКАЗНИКІВ ЗАПЛІДНЮВАНОСТІ ЗА ВАКЦИНАЦІЇ КОРІВ ПРОТИ СИБІРКИ
}

\author{
Титух Ярослав Вікторович \\ аспірант кафедри акушерства і хірургії \\ Сумський національний аграрний університет (м. Суми, Україна) \\ ORCID: 0000-0002-2504-0928 \\ yaroslavusvet@gmail.com
}

Байдевлятов Юрій Анварович

кандидат ветеринарних наук, доцент,

Сумський національний аграрний університет (м. Суми, Україна)

ORCID: 0000-0001-5042-7414

yurii.baydevlatov@snau.edu.ua

Ребенко Галина Іванівна, кандидат вет. наук, доцент, Сумський національний аграрний університет (м. Суми, Україна) ORCID: 0000-0002-1884-4901, halyna.rebenko@snau.edu.ua

Мусієнко Юрій Володимирович кандидат ветеринарних наук, доцент Сумський національний аграрний університет (м. Суми, Україна) ORCID: 0000-0002-9735-4758 musik_ne@ukr.net

Показник запліднюваності є одним з маркерів ефективність галузі тваринництва, проте благополучному утворенню і закріпленню зиготи в слизовій оболонці матки можуть перешкоджати не лише різні запальні процеси, а й імунологічні реакції поствакцинального комплексу.

Попередні спостереження за станом запліднюваності корів в господарстві вказували на суттєве зниження цього показника як раз після проведення вакцинації проти сибірки. Результати досліджень, наведені в статті показують достовірне зменшення показника запліднюваності. На нашу думку, це пов'язане з імунологічними процесами в організмі провакцинованих корів, яких осіменяли. Тобто, стимульована під час вакцинації імунна система не здатна гальмувати свою роботу в окремо взятих статевих шляхах, тому й заважає прикріпленню успішно утвореної при заплідненні зиготи до слизової матки, що в підсумку закінчується безпліддям і настанням повторної охоти.

Отримані результати дозволяють стверджувати, що вакцинація тварин проти сибірки і особливо період активного формування поствакцинального специфрічного імунітету знижують показники відтворення у корів: показники запліднюваності знижувалися на 16,2\% протягом першого тижня після вакцинації та на 50\% протягом другого у порівнянні 3 показниками тварин, які осіменялися до початку вакцинації

З'ясовано, що у корів, яких осіменяли під час імунологічного навантаження, відмічене збільшення тривалості термінів неплідності - відповідно на 12,7\% та 38,6\%.

Економічні розрахунки показали, що збитки від недоотримання телят в групі корів, осіменених безпосередньо після вакцинації, були в 2,7 разів більші, а в групі корів, осіменених на другому тижні після вакцинації, - відповідно в 3,5 рази вищі, ніж у корів, яких осіменяли до вакцинації. Збитки від недоотримання молока в цих групах збільшилось відповідно на $7,6 \%$ ma $38,4 \%$.

Ключові слова: показники запліднюваності, штучне запліднення, вакцинація проти сибірки, економічні збитки.

DOI: https://doi.org/10.32845/bsnau.vet.2020.4.1

Вступ. Показник запліднюваності, як один з маркерів ефективність галузі тваринництва, залежить від цілого ряду факторів, серед яких запальні явища статевих шляхів самок (найчастіше ендометрити), якість сперми, дотримання термінів та кондицій. Фізіологічне середовище в статевих шляхах має забезпечити благополучне утворення зиготи, проте не лише запальні процеси заважають в цьому випадку. Імунологічні реакції поствакцинального комплексу також здатні впливати на запліднюваність.

Створення належних умов утримання поголів'я, виконання комплексу рекомендацій щодо повноцінної і якісної годівлі тварин, організація і своєчасне проведення оздоров-

чих і профілактичних заходів дозволяють підтримувати благополуччя господарств різної форми власності стосовно інфекційних і незаразних хвороб, а також отримувати високі показники продуктивності тварин і продукцію належної якості у відповідності до стандартів. До списку особливо небезпечних хвороб, проти яких запроваджена обов'язкова щорічна вакцинація всіх видів сприйнятливих тварин, є сибірка. Для імунізації використовують живу вакцину, застосування якої вимагає розуміння можливих небажаних наслідків та вжиття заходів з їх запобігання.

Аналіз останніх досліджень та публікацій. Спороутворююча бактерія Bacillus anthracis - збудник сибірки - 
розповсюджена практично всюди, де є тваринництво, в тому числі і в Україні. За повідомленням Рубленко І.О. (2018) лише на території України знаходиться більше 13,5 тис. захоронень тварин, що загинули від сибірки. Поширеність цього мікроорганізму та його стійкість в довкіллі створюють передумови стаціонарного неблагополуччя територій і постійної загрози зараження свійської худоби, попередити яку можна лише охопленням профілактичними щепленнями усього поголів'я тварин (Rublenko, I.O., 2018).

3 часів запровадження першої ефективної живої протисибіркової вакцини Л. Пастера було запропоновано декілька варіантів засобів для активної імунізації. Більшість ветеринарних вакцин в світі використовують токсигенні безкапсульні (pX01 + / pX02-) штами Bacillus anthracis Stern 34F2, K79Z, СБ, UA-07, тощо, які забезпечують імунний захист шляхом утворення нейтралізуючих антитіл до компонентів сибіркового токсину: протективного антигену, летального фактору та фрактору набряку (Adone, R., Sali, M., Francia, M., latarola, M., Donatiello, A., Fasanella, A., 2016, Rublenko, I.O., 2018).

Не зважаючи на визнаний основний спосіб зараження людей від хворих тварин та через контаміновану продукцію тваринництва - тобто типовий зооноз, - останнім часом Bacillus anthracis віднесено до мікроорганізмів з високим потенціалом використання за біотероризму (Spickler, A.R., 2017). Випадки застосування спор сибірки для соціальнополітичної дестабілізації широко відомі. Так, ще у 2001 році B. Anthracis, використана як біологічна зброя, призвела до захворювання 22 осіб та смерті 5. (Martin E. Hugh-Jones, 2015). Отже, застосування вакцин проти сибірки є актуальним не лише для попередження хвороби у тварин. Люди, що входять до груп ризику, також мають бути захищені за допомогою вакцинопрофілактики.

Для пре-експозиційної імунізації людей, наприклад, в США та Європі застосовують субодиничні вакцини з очищених білків B. anthracis (Arthur M. Friedlander, John D. Grabenstein, Philip S. Brachman, Stanley A. Plotkin, Walter A. Orenstein, Paul A. Offit, Kathryn M. Edwards, 2018).

Таку вакцину отримують шляхом кон'югування капсули з білковим носієм. Кон'югована вакцина проти капсули B. anthracis, індукована антитілами до опсоно-адгезії. Вона ефективна проти інгаляційної форми зараження сибіркою. Капсульна вакцина виявилася першою не пов'язаною з токсином-антигеном (Chabot, D.J., Joyce, J., Caulfield, M., Cook, J., Hepler, R., Wang, Su, Vietri, N. J., Ruthel, G., Shoop, W., Pitt, L., Leffel, E., Ribot, W., Friedlander, A. M. (2012)..

Доведено багатьма дослідженнями, що потрапляння антигену в організм викликає цілий ряд специфічних та неспецифічних реакцій, які в більшості випадків спричиняють негативний вплив на різні органи і системи, перебудову їх функціональної діяльності, відтворюючи легку форму перебігу захворювання.

До найпоширеніших ризиків, пов'язаних з вакцинами, належать залишкова токсичність, яка може спричинити реакції на місці ін'єкції, депресію, алергічні реакції, захворювання імуноскомпроментованих господарів (особливо модифіковані живі вакцини), неврологічні ускладнення та іноді загострення прихованих інфекцій, спричинених іншими патогенами. Вакцини, що містять вбиті грамнегативні організми, можуть також містити сліди ендотоксинів, які стимулюють вивільнення інтерлейкіну-1 і можуть спричинити лихо- манку та лейкопенію, а іноді і аборти (Ian Tizard, 2020).

Сама процедура імунізації є додатковим стресом для організму, особливо в періоди зниженої резистентності, фізичної ослабленості, вагітності, тощо. Застереження щодо використання живих спорових вакцин з безкапсульних штамів Bacillus anthracis для вагітних тварин вказані навіть в OIE Terrestrial Manual (2018).

Таким вразливим періодом за даними дослідників $€$ процеси осіменіння та запліднення самок, які регулюються різними групами гормонів і в повній мірі залежать від загального стану організму та адекватності імунологічних реакцій, особливо реакцій гальмування імунної відповіді, для попередження деактивації сперматозоїдів, а також відторгнення ембріона.

Американські дослідники, що вивчали питання вакцинації проти сибірки з метою запобігання зараженню, якщо B. anthracis використовується як біологічна зброя, але довгостроковий вплив вакцинації проти сибірки на репродуктивний результат був невідомий, поки William H. Catherino, Andrew Levi, Tzu-Cheg Kao, Mark P. Leondires, Jeffrey McKeeby та James H. Segars (2005) не встановили, що вакцина проти сибірки для чоловіків, яким її вводили, не впливала негативно на параметри сперми, рівень запліднення, якість ембріонів чи клінічну вагітність.

Вивчення залежності побічних реакцій в поствакцинальному періоді за використання протисибіркових вакцин від статі вакцинованих виявило більшу частоту ускладнень у самок за підвищеного рівня статевих гормонів. (Tracy Pondo, Charles E. Rose, Stacey W. Martin, Wendy A. Keitel, Harry L. Keyserling, Janiine Babcock, Scott Parker, Robert M. Jacobson, Gregory A. Poland, Michael M. McNeil 2014)

В доступній нам літературі існують відомості, що зростаюча кількість жінок вакцинується протягом дітородних років вакциною BioThrax® (адсорбована вакцина проти антраксу або AVA). Існує обмежена кількість досліджень на людях, щодо впливу AVA на репродуктивне здоров'я. AVA безпосередньо або опосередковано через вироблення антиPA lgG, як видається, не чинить несприятливого впливу на вагітних або їх потомство, як вимірюється за показниками спаровування та народжуваності, спостереженнями природних пологів, клінічними ознаками, внутрішньоутробного росту і виживання, морфологічного розвитку та життєздатності плоду. Проте, у жінок, щеплених вакциною проти сибірки AVA, знижений рівень прогестерону в сироватці крові до вакцинації був пов'язаний 3 порушенням водноелектролітного балансу і подальшим розвитком набряку руки в місці введення. Введення вакцини AVA з урахуванням менструальної фази жінки може зменшити появу певних реакцій у місці ін'єкції (Zhang, Y., Martin, S.W., Rose Jr., C.E., Biagini, R.E., Franzke, L.H., Smith, J.P., Sammons, D.L., Robertson, S.A, McNeil, M.M., 2008).

Найбільш поширеними побічними явищами, які оцінювали як пов'язані з вакцинацією BioThrax та AV7909, були реакції на місці ін'єкції. Транзиторна лімфопенія спостерігалася після першої дози в кожній групі. Частота реакції в місці ін'єкції та системні реакції були зафріксовані суб'єктами у щоденниках протягом 7 днів після кожної ін'єкції. У дослідженні не спостерігалося особливих цікавих явищ (аутоімунних подій) 9Robert J. Hopkins, Nancy F. Daczkowski, Paulina E. Kaptur, Derek Muse, Eric Sheldon, Craig LaForce, Suha Sari, Thomas L. Rudge, Edward Bernton, 2013). 
Розглядаючи питання імуногенезу, ми знайшли повідомлення Kern, J. та Schneewind, O. (2010), що мікробні патогени використовують поверхневі клейкі білки, щоб зв'язуватися з тканинами хазяїна та взаємодіяти з ними. BsIA, білок S-шару, є необхідним та достатнім для адгезії вакцинного штаму Bacillus anthracis Sterne, до клітингосподарів. Порівняно з надзвичайно вірулентним батьківським штамом B. anthracis Ames, мутанти bslA демонстрували різке збільшення летальної дози та середнього часу до смерті. У той час як усі тканини тварин, інфікованих В. anthracis Ames, містили велику кількість паличок, лише кілька вегетативних фрорм можна було відновити з внутрішніх органів тварин, інфікованих мутантом bsIA. BsIA на поверхні (на полюсах інкапсульованих паличок) забезпечував зв'язування вегетативних форм 3 клітинами-господарями, тобто функціонував як поверхневий адгезин.

Екзотоксини, що виділяються В. anthracis, використовують білок капілярного морфогенезу 2 (CMG2) як головний рецептор токсину і відіграють важливу роль у патогенезі протягом усього перебігу захворювання (Liu, S., Moayeri, M., Leppla, S.H, 2014).

Введення набрякового токсину, як зазначають Firoved, A.M., Miller, G.F., Moayeri, M., Kakkar, R., Shen, Y., Wiggins, J.F., McNally, E.M., Tang, W.-J., Leppla, S.H. (2005), призводить до збільшення кількості цитокінів, включаючи гранулоцитарний колонієстимулюючий фактор, еотаксин, цитокін, що походить від кератиноцитів, МСР-1 / JE, інтерлейкін-6, інтерлейкін-10 та інтерлейкін-10. Фізіологічні вимірювання також виявили одночасну гіпотензію та брадикардію.

Місця введення вакцин проти сибірки (вбитої КВМА та живої HBSS) оцінювали Skoble, J., Beaber, J.W., YiGao, Lovchik, J.A., Sower, L.E., Liu, W., Luckett, W., Peterson, J. W., Calendar, R., Portnoy, D. A., Lyons, C. R. and Dubensky, T.W. Jr. (2009). Сліпе рандомне дослідження на ступінь тяжкості запалення на основі наявності нейтрофрілів та мононуклеарних клітин або пошкодження міоцитів в місці введення. Запалення в групі, яка отримувала вакциновану KBMA, досягло максимуму через 1 день після первинної вакцинації і не відрізнялося від запалення, яке було введено HBSS через 1 тиждень. У тварин, вакцинованих спорами живої вакцини, запалення поступово наростало до 14-го дня, залишалося високим до 21-го дня.

Fasanella, A., Tonello, F., Garofolo, G., Muraro, L., Carattoli, A., Adone, R., Montecucco C. (2008) досліджували поствакцинальні реакції на рекомбінантну вакцину проти сибірки. Системних реакцій не спостерігалося: ані симптомів токсинемії або бактеріємії сибірки, ані температури або чутливості. На місці ін'єкції спостерігався лише тимчасовий локальний набряк, ймовірно, через масляну суміш, але макроскопічних ознак некрозу не спостерігалося

Отже, як бачимо з попередніх повідомлень, усі види вакцин проти сибірки давали незначні або місцеві реакції, які ніяк не могли стосуватися слизової оболонки статевих шляхів. Яким іншим чином проведення вакцинації могло вплинути на показники запліднюваності. Відомо, що вагітність 3 ранніх термінів пов'язана з обширними імунологічними адаптаціями в організмі, які змінюють імунологічну реактивність до багатьох захворювань,

Імунна система слизової самиць може розпізнавати алогенні специсрічні для сперматозоїдів білки, що впливають на кінематику сперми та зони зв'язування сперматозоїдів, що призводить до імунного безпліддя. Archana, SS, Selvaraju, S, Binsila, BK, Arangasamy, A, Krawetz, SA. (2019) зазначають, що середовище цитокінів і лейкоцитів, що створюється спермою в жіночих репродуктивних шляхах, переважно в шийці матки, збільшує експресію генів запальної та імунної відповіді. В матці прозапальні хемокіни, цитокіни та макрофаги допомагають захистити алогенні сперматозоїди в жіночих репродуктивних шляхах. Під час неінфікованих умов клітини ендометрію можуть секретувати Т-клітини, що несуть CD25, CD59, тоді як клітини трофообластів виділяють додаткові регуляторні білки, такі як CD55 і CD46, що, в свою чергу, допомагає встановити бластоцисту в матці.

Hansen, P. J. (2007) також підтверджує думку,що вагітність призводить до зміни кількості та функції імунних клітин статевих шляхів самки, що потенційно впливає на виживання плода та захисні механізми матки після пологів. Ці зміни регулюються сигналами від пладу, а також гормональними змінами, спричиненими плацентою або материнським організмом. Т-клітини накопичуються в епітелії матки під час вагітності і можуть брати участь у рості пладу, імунодепресії або відшаруванні плаценти при пологах.

Це відбувається завдяки прогестерону, пригнічує імунну відповідь матки, викликаючи в епітелії ендометрію секрецію інгібітора серинової протеїнази, що називається маточним серпіном. Серпін матки може блокувати проліферацію лімфоцитів in vitro та клітин-кіллерів, що зумовлюють аборт in vivo у мишей. Відповідність змін імунної функції матки репродуктивному та імунному статусу жуйних тварин до кінця не встановлена. $€$ дані про імунологічні причини втрати вагітності,

Оптимальна імунна функція статевих шляхів самки вимагає балансу між необхідністю підтримувати ефективний імунний нагляд та ефекторними механізмами 3 вимогою мінімізувати імунологічні реакції, що ведуть до загибелі плоду.

Про випадки порушення відтворної функції, пов'язаної 3 вакцинацією проти сибірки повідомляли Bassuino, D.M., Siqueira, F.M., Konradt, G., Vielmo, A., Rolim, V.M., Gonçalves M.A., Cibulski S.P., Snel, G., MayerF.Q., Castagna de Vargas A. Driemeier, D. Pavarini, S.P. (2020), зазначивши при цьому, що хоча вакцинація проти сибірської виразки характеризується підвищеним захисним профілем та дуже низькою залишковою вірулентністю, імунізація вакциною з штаму Sterne може спричинити аборт у великої рогатої худоби, імовірно, плазмідними токсинами рX01 у рідкісних або особливих ситуаціях .Ідентифікація $B$. anthracis була підтверджена виявленням молекулярного хромосомного маркера Ва813. Геномі з ізольованого В. anthracis (з назвою SPV842_15) та з ізольованого вакцинного штаму (бразильського вакцинного штаму), який був вилучений з комерційної вакцини, що застосовується у вагітної корови, були секвенировани. Геномні порівняння показали високий рівень ідентичності нуклеотидів у порівняннях між $B$. anthracis SPV842_15 та бразильським вакцинальним штамом $B$. anthracis (98,2\%). Крім того, в обох штамах була виявлена лише послідовність плазміди рХ01.

Мануйлов А.В. (2004) вказував, що висока імунологічна реактивність організму корів під час формування та розвитку плода свідчить про відсутність адекватних взаємин у системі «мати-плацента-плід», а також про недостатню 
взаємну толерантність. Зміна імунного статусу організму корови під час вагітності в сторону його специфічної і неспецифічної активізації (що спостерігається при введенні їй вакцинних антигенів), позначається на рефрактерности зародка, на взаємній толерантності його організму і організму матері, на нормальному функціонуванні її репродуктивної системи.

Метою нашої роботи було вивчення впливу вакцинопрофілактики проти сибірки на стан відтворної функції корів в умовах господарства ТОВ «Агрофрірма Лан» Сумського району Сумської області.

Матеріали і методи досліджень. Дослідження проводились на поголів'ї великої рогатої худоби голштинської породи ТОВ «Агрофірма Лан» Сумського району Сумської області

Вакцинація проти сибірки проводилася вакциною живою споровою проти сибірки тварин із штаму «СБ» виробництва Сумської біологічної фабрики відповідно до плану заходів з профілактики заразних хвороб, затвердженого для Сумського району, а також згідно з настановою по застосуванню вакцини.

Для оцінки впливу проведеної імунізації на репродуктивну здатність корів було сформовано 3 дослідні групи: перша група - корови, осіменіння яких відбулося до вакцинації, друга - осіменіння відбувалося під час і протягом 1-6 днів після вакцинації проти сибірки, і третя група - тварини, що прийшли в охоту і осіменялися з 7-го по 14 день після вакцинації. Штучне осіменіння проводилося ректоцервікальним методом. При цьому застосовували одноразовий стерильний інструмент для введення спермодози у цервікальний канал тварин у вигляді паєт (пакетів, соломинок) з размороженою спермою.

Тварини утримувалися в аналогічних умовах, для них застосовували однаковий раціон, режим годівлі та технологічні маніпуляції.

За тваринами усіх трьох груп встановили контроль клінічного стану. Фіксувалися терміни настання статевої охоти.

Визначали показники запліднюваності за результатами УЗД діагностики, аналізували відсоток запліднених корів та тривалість неплідності по групам.

За отриманими результатами проводили розрахунки економічних збитків від збільшення періоду неплідності, виражені в недоотриманні приплоду та недоотриманні молока, згідно загальноприйнятої методики визначення економічної ефективності ветеринарних заходів, використовуючи актуальні для даного господарства на момент розрахунків закупівельні ціни.

\section{Результати досліджень}

Для визначення результативності штучного осіменіння в господарстві і подальшого використання цього показника як базового для аналізу впливу проведення вакцинації корів проти сибірки, ми провели визначення показників запліднюваності у корів, які увійшли в групу 1. Середньорічні показники в цьому випадку не можуть бути використані у зв'язку з їх коливанням в залежності від сезону. Запліднюваність у весняну пору року стабільно нижче середньорічної за останні 3 роки, а план профілактичних протиепізоотичних заходів передбачає щеплення проти сибірки завчасно перед початком пасовищного сезону.

Дані таблиці 1 свідчать про те, що в групі тварин, які осіменялись до початку вакцинації проти сибірки із загальної кількості 23 голови запліднилось 10 голів. При цьому середній по групі показник запліднюваності складав 43,4 \%, тривалість неплідності по групі впродовж місяця становила 390 днів, що в перерахунку на 1 голову складала 16,95 днів.

Таблиця 1

Результати осіменіння корів до вакцинації проти сибірки

\begin{tabular}{|c|c|c|c|c|c|c|c|c|}
\hline \multirow{2}{*}{$\begin{array}{c}\text { Bсього } \\
\text { голів }\end{array}$} & \multicolumn{3}{|c|}{ Прийшло в охоту і осіменено } & \multirow{2}{*}{ Тільних } & \multirow{2}{*}{ Запліднюваність, \% } & \multirow{2}{*}{$\begin{array}{c}\text { Cередня запліднюваність } \\
\text { по групі, \% } \\
\end{array}$} & \multirow{2}{*}{$\begin{array}{c}\text { Днів неплідності по } \\
\text { групі }\end{array}$} & \multirow{2}{*}{$\begin{array}{c}\text { В перерахунку } \\
\text { на } 1 \text { голову }\end{array}$} \\
\hline & № охоти & голів & $\%$ & & & & & \\
\hline \multirow{4}{*}{23} & 1 & 9 & 39,0 & 2 & 22,0 & \multirow{4}{*}{43,4} & \multirow{4}{*}{390} & \multirow{4}{*}{16,95} \\
\hline & II & 2 & 8,7 & 0 & 0 & & & \\
\hline & III & 7 & 30,4 & 5 & 71,0 & & & \\
\hline & IV & 5 & 21,7 & 3 & 60,0 & & & \\
\hline
\end{tabular}

В групі тварин, осіменіння яких співпало в часі з періодом проведення вакцинації і в найближчі за вакцинацією дні спостерігалося незначне зниження результативності штучного осіменіння (таблиця 2). Так, середній по групі показник запліднюваності становив 36,4 \%, що помітно нижче, ніж у першій дослідній групі. Тривалість неплідності була на 30 днів по групі більше і в перерахунку на 1 голову була вищою - 19,1\%.

Таблиця 2

Результати осіменіння корів в період вакцинації проти сибірки

\begin{tabular}{|c|c|c|c|c|c|c|c|c|}
\hline \multirow{2}{*}{$\begin{array}{c}\text { Всього } \\
\text { голів }\end{array}$} & \multicolumn{3}{|c|}{ Прийшло в охоту і осіменено } & \multirow[b]{2}{*}{ Тільних } & \multirow{2}{*}{$\begin{array}{c}\text { Запліднюваність, } \\
\%\end{array}$} & \multirow{2}{*}{$\begin{array}{c}\text { Середня запліднюваність } \\
\text { по групі, \% } \\
\end{array}$} & \multirow{2}{*}{$\begin{array}{c}\text { Днів неплід-ності по } \\
\text { групі }\end{array}$} & \multirow{2}{*}{$\begin{array}{c}\text { В перерахунку на } \\
1 \text { голову } \\
\end{array}$} \\
\hline & № охоти & голів & $\%$ & & & & & \\
\hline \multirow{4}{*}{22} & I & 8 & 36,4 & 1 & 12,5 & \multirow{4}{*}{36,4} & \multirow{4}{*}{420} & \multirow{4}{*}{19,1} \\
\hline & II & 4 & 18,2 & 3 & 75,0 & & & \\
\hline & III & 6 & 27,3 & 3 & 50,0 & & & \\
\hline & IV & 4 & 18,2 & 1 & 25,0 & & & \\
\hline
\end{tabular}

Суттєве зниження рівня запліднюваності спостерігалося в групі, корови якої були піддані осіменнінню на другому тижні після завершення вакцинації, в період, коли імунна система тварин, потужно простимульована живою вакциною, як раз активно напрацьовувала специсрічні антитіла.
Дані по цій групі наведені в таблиці 3. Середній показник по групі становив 21,7 \%, що вдвічі нижче, ніж показали тварини 3 першої групи. Тривалість неплідності на 1 голову складала 23,5 днів. 
Таблиця 3

Результати осіменіння корів через 7 днів після вакцинації проти сибірки

\begin{tabular}{|c|c|c|c|c|c|c|c|c|}
\hline \multirow{2}{*}{$\begin{array}{l}\text { Всього } \\
\text { голів }\end{array}$} & \multicolumn{3}{|c|}{ Прийшло в охоту і осіменено } & \multirow[b]{2}{*}{ Тільних } & \multirow[b]{2}{*}{ Запліднюваність, \% } & \multirow{2}{*}{$\begin{array}{c}\text { Середня запліднюваність } \\
\text { по групі, \% }\end{array}$} & \multirow{2}{*}{$\begin{array}{c}\text { Днів неплідності } \\
\text { по групі }\end{array}$} & \multirow{2}{*}{$\begin{array}{c}\text { В перерахунку на } \\
1 \text { голову }\end{array}$} \\
\hline & № охоти & голів & $\%$ & & & & & \\
\hline \multirow{4}{*}{23} & I & 15 & 65,2 & 2 & 13,3 & \multirow{4}{*}{21,7} & \multirow{4}{*}{540} & \multirow{4}{*}{23,5} \\
\hline & II & 2 & 8,7 & 1 & 50,0 & & & \\
\hline & III & 3 & 13,0 & 0 & 0 & & & \\
\hline & IV & 3 & 13,0 & 2 & 66,6 & & & \\
\hline
\end{tabular}

Таким чином, результати свідчать про те, що і сама вакцинація, і особливо період активного формування поствакцинального імунітету проти сибірки негативно впливають на показники відтворення у корів. При цьому суттєво знижу-

ються показники запліднюваності - відповідно на 16,2\% та на 50\% (рис 1), а також збільшується тривалість термінів неплідності - відповідно на 12,7\% та 38,6\%.

запліднюваність в групі, \%

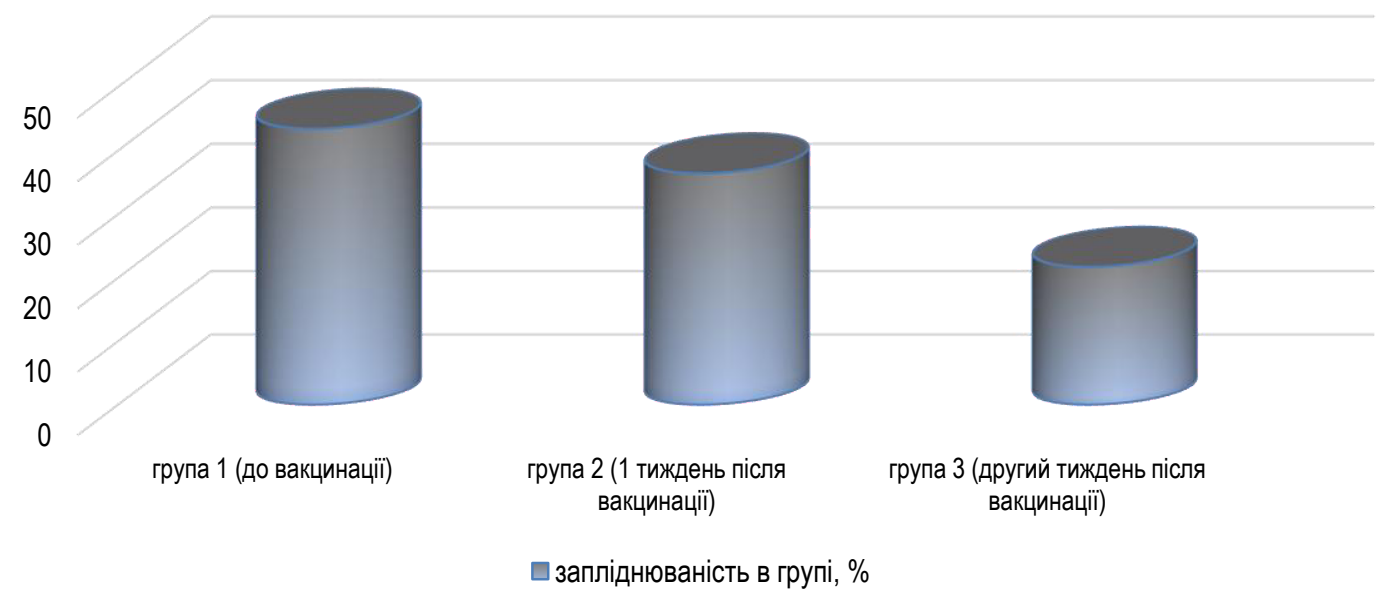

Рис 1. Залежність показників запліднюваності від проведення вакцинації проти сибірки

Зниження запліднюваності призводить до збільшен- $\mid$ приплоду та вподальшому, молока, що помітно відображуня періоду неплідності, а відповідно до недоотримання ється на економічних показниках господарства (таблиця 4).

Таблиця 4

Економічні збитки від втрати продуктивності корів

\begin{tabular}{|c|c|c|c|c|}
\hline Групи корів & $\begin{array}{c}\text { Недоотримано молока, } \\
\text { ц/ грн }\end{array}$ & $\begin{array}{l}\text { Недоотримано телят } \\
\text { (голів) }\end{array}$ & $\begin{array}{l}\text { Сума збитків } \\
\text { (грн.) }\end{array}$ & $\begin{array}{c}\text { Сума збитків в } \\
\text { перерахунку на } 1 \text { голову }\end{array}$ \\
\hline \multirow{2}{*}{ До вакцинації } & 11,7 & 1,24 & \multirow{2}{*}{13490,6} & \multirow{2}{*}{586,5} \\
\hline & 11700 & 1790,6 & & \\
\hline \multirow{2}{*}{ Під час вакцинації } & 12,6 & 1,33 & \multirow{2}{*}{17401,3} & \multirow{2}{*}{790,9} \\
\hline & 12600 & 4801,3 & & \\
\hline \multirow{2}{*}{ На другому тижні після вакцинації } & 16,2 & 1,71 & \multirow{2}{*}{22373,1} & \multirow{2}{*}{972,7} \\
\hline & 16200 & 6173,1 & & \\
\hline
\end{tabular}

Розраховуючи показники економічних збитків від недоотримання продукції слід зазначити, що, враховуючи в цілому великі терміни неплідності по господарству в цей період часу, більшу частину збитків становлять втрати виручки за молоко. А по групах тварин, що осіменялися під час імунологічного навантаження, суттєвий внесок в економічні збитки мають втрати від недоотримання телят. В другій дослідній групі (осіменених безпосередньо після вакцинації) ці збитки були в 2,7 разів більші, ніж в першій, а в третій (осіменених на другому тижні після вакцинації) - відповідно в 3,5 рази. Збитки від недоотримання молока в цих групах збільшилось відповідно на 7,6 \% та 38,4\%. (рис 2.) 


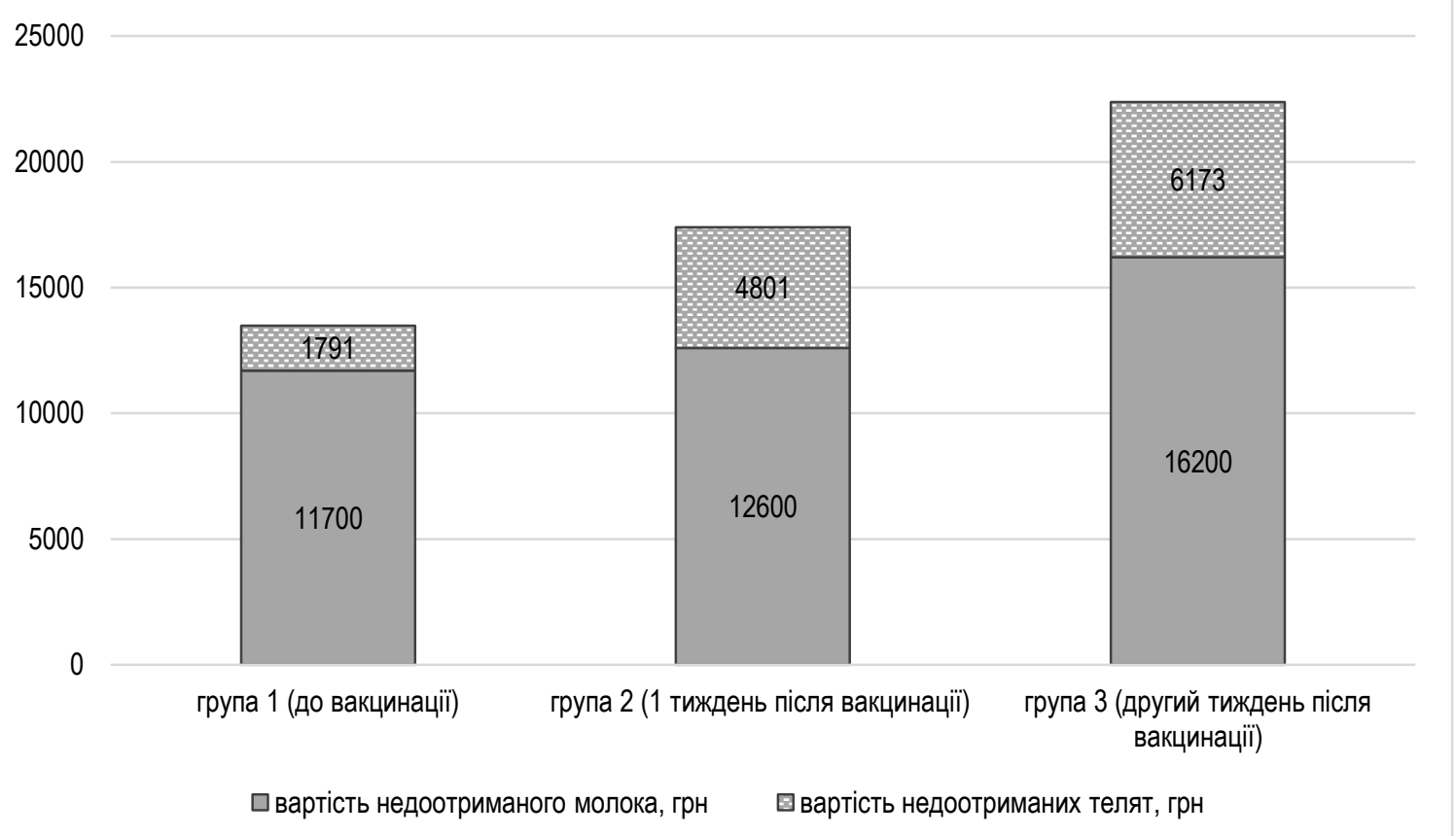

Рис 2. Грошові втрати від недоотримання продукції по групам до і після проведення вакцинації корів проти сибірки

Вартість від втрати продукції в перерахунку на 1 корову збільшилась відповідно по групам на 204, 4 грн та на 386,2 грн у порівнянні 3 групою тварин, які осіменялися до вакцинації.

\section{Обговорення}

Отже, багаторічні попередні спостереження за станом запліднюваності корів в господарстві вказували на різке зниження цього показника як раз після проведення вакцинації проти сибірки. Результати досліджень, наведені в статті показують достовірне зменшення показника запліднюваноcтi.

На нашу думку, це пов'язане з імунологічними процесами в організмі провакцинованих корів, яких осіменяли. Описані П. Хансеном (2007) гормонально-імунологічні механізми пригнічення імунної відповіді матки допомагають закріпленню бластоцисти в слизовій матки. Отже, стимульована під час вакцинації імунна система не здатна гальмувати свою роботу в окремо взятих статевих шляхах, тому й заважає прикріпленню успішно утвореної при заплідненні зиготи до слизової матки, що в підсумку закінчується безпліддям і настанням повторної охоти.

Про відсутність адекватних взаємин у системі «матиплацента-плід», а також про недостатню взаємну імунологічну толерантність внаслідок специфічної активізації імунітету вказував також Мануйлов А.В. (2004).

Бразильські вчені Bassuino, D.M., Siqueira, F.M.,зі співавторами (2020), відзначили. Що в окремих випадках імунізація вакциною проти сибірки з штаму Sterne може спричинити навіть аборт у великої рогатої худоби.

Перспективи досліджень з даного напрямку.

Для подальших досліджень варто було б глибше зрозуміти імунологічні підстави такого виду неплідності, визначити, чи інші вакцини (особливо живі) мають подібний вплив, знайти способи обійти тимчасову гіперактивізацію імунної системи локально для слизової статевих шляхів, щоб мінімізувати втрати.

\section{Висновки.}

1. Вакцинація проти сибірки і особливо період активного формування поствакцинального імунітету знижують показники відтворення у корів: показники запліднюваності знижувалися на 16,2\% протягом першого тижня після вакцинації та на 50\% протягом другого у порівнянні з показниками тварин, які осіменялися до початку вакцинації

2. У корів, яких осіменяли під час імунологічного навантаження, відмічене збільшення тривалості термінів неплідності - відповідно на $12,7 \%$ та $38,6 \%$.

3. Економічні збитки від недоотримання телят в групі корів, підданих осімененню безпосередньо після вакцинації, були в 2,7 разів більші, а в групі корів, осіменених на другому тижні після вакцинації, - відповідно в 3,5 рази вищі, ніж у корів, яких осіменяли до вакцинації. Збитки від недоотримання молока в цих групах збільшилось відповідно на $7,6 \%$ та $38,4 \%$

\section{References}

1. Adone, R., Sali, M., Francia, M., latarola, M., Donatiello, A., Fasanella, A. (2016). Development of a Sterne-Based Complement Fixation Test to Monitor the Humoral Response Induced by Anthrax Vaccines. Frontiers in Microbiology, 7, 19. DOI=10.3389/fmicb.2016.00019. Available from: https://www.frontiersin.org/article/10.3389/fmicb.2016.00019 [accessed Sep 23 2020].

2. Archana, SS, Selvaraju, S, Binsila, BK, Arangasamy, A, Krawetz, SA. (2019). Immune regulatory molecules as modifiers of semen and fertility: A review. Mol Reprod Dev., 86: 1485- 1504. https://doi.org/10.1002/mrd.23263

3. Archana, SS, Selvaraju, S, Binsila, BK, Arangasamy, A, Krawetz, SA. Immune regulatory molecules as modifiers of semen and fertility: A review. Mol Reprod Dev. 2019; 86: 1485- 1504. https://doi.org/10.1002/mrd.23263 
4. Arthur M. Friedlander, John D. Grabenstein, Philip S. Brachman, Stanley A. Plotkin, Walter A. Orenstein, Paul A. Offit, Kathryn M. Edwards. (2018). Plotkin's Vaccines (Seventh Edition), Anthrax Vaccines, Elsevier, $134-148$. https://doi.org/10.1016/B978-0-323-35761-6.00011-0.

5. Bassuino, D.M., Siqueira, F.M., Konradt, G., Vielmo, A., Rolim, V.M., Gonçalves M.A., Cibulski S.P., Snel, G., MayerF.Q., Castagna de Vargas A. Driemeier, D. Pavarini, S.P. (2020) Bovine abortion by a vaccine strain of Bacillus anthracis Ciência Rural 50(12). DOI: 10.1590/0103-8478cr20200264. Available from: https://www.researchgate.net/publication/344324108_Bovine_abortion_by_a_vaccine_strain_of_Bacillus_anthracis [accessed Oct 2 2020

6. Chabot, D.J., Joyce, J., Caulfield, M., Cook, J., Hepler, R., Wang, Su, Vietri, N. J., Ruthel, G., Shoop, W., Pitt, L., Leffel, E., Ribot, W., Friedlander, A. M. (2012). Efficacy of a capsule conjugate vaccine against inhalational anthrax in rabbits and monkeys. Vaccine, 30, 5, 846-852. https://doi.org/10.1016/j.vaccine.2011.12.010.

7. Fasanella, A., Tonello, F., Garofolo, G., Muraro, L., Carattoli, A., Adone, R., Montecucco C. (2008). Protective activity and immunogenicity of two recombinant anthrax vaccines for veterinary use. Vaccine 26(45), 5684-5688. DOI:10.1016/j.vaccine.2008.08.026

8. Firoved, A.M., Miller, G.F., Moayeri, M., Kakkar, R., Shen, Y., Wiggins, J.F., McNally, E.M., Tang, W.-J., Leppla, S.H. (2005). Bacillus anthracis edema toxin causes extensive tissue lesions and rapid lethality in mice. American Journal of Pathology, $167,5,1309-1320$.

9. Franco, C., Lewis, E., Morseth, S., Simon, L., Waytes, A.T. (2009). Reproductive toxicity of BioThrax® in rabbits. Birth Defects Research Part B - Developmental and Reproductive Toxicology, 86, 5, 370-376

10. Hansen, P. J. (2007). Regulation of immune cells in the uterus during pregnancy in ruminants. Journal of Animal Science, 85, E30-E31.

11. Hansen, P. J. (2007). Regulation of immune cells in the uterus during pregnancy in ruminants. Journal of Animal Science, 85, E30-E31.

12. Ian Tizard (2020) Vaccine Failure and Other Adverse Events in Animals. At https://www.merckvetmanual.com/pharmacology/vaccines-and-immunotherapy/vaccine-failure-and-other-adverse-events-in-animals

13. Ibrahim, L. A., Rizo, J. A., Fontes, P. L. P., Lamb, G. C., \& Bromfield, J. J. (2018). Seminal plasma modulates expression of endometrial inflammatory meditators in the bovine. Biology of Reproduction, 100, 660-671.

14. Ionin, B., Hopkins, R.J., Pleune, B., Sivko, G.S., Reid, F.M., Clement, K.H., Rudge Jr., T.L., Stark, G.V., Innes, A., Sari, S., Guina, T., Howard, C., Smith, J., Swoboda, M.L., Vert-Wong, E., Johnson, V., Nabors, G.S., Skiadopoulos, M.H. (2013). Evaluation of immunogenicity and efficacy of anthrax vaccine adsorbed for postexposure prophylaxis. Clinical and Vaccine Immunology, 20, 7, 1016-1026

15. Kern, J., Schneewind, O. (2010). BsIA, the S-layer adhesin of B. anthracis, is a virulence factor for anthrax pathogenesis. Molecular Microbiology, 75, 2, 324-332

16. Liu, S., Moayeri, M., Leppla, S.H. (2014). Anthrax lethal and edema toxins in anthrax pathogenesis. Trends in Microbiology, 22, 6, 317-325

17. Manuilov AV (2004) Vlyianye vaktsynoprofylaktyky ynfektsyonnыkh boleznei na vosproyzvodytelnuiu funktsyiu korov. [Influence of vaccine prophylaxis of infectious diseases on reproductive function of cows]. Dyss kand vet nauk [PhD thesises], 16. [in Russian]

18. Marey, M. A., Liu, J., Kowsar, R., Haneda, S., Matsui, M., Sasaki, M., ... Miyamoto, A. (2014). Bovine oviduct epithelial cells downregulate phagocytosis of sperm by neutrophils: Prostaglandin E2 as a major physiological regulator. Reproduction, 147, 211-219.

19. Marey, M. A., Yousef, M. S., Kowsar, R., Hambruch, N., Shimizu, T., Pfarrer, C., \& Miyamoto, A. (2016). Local immune system in oviduct physiology and pathophysiology: Attack or tolerance, Domestic Animal Endocrinology, 56, S204-S211.

20. Martin E. Hugh-Jones (2015). Overview of Anthrax. https://www.merckvetmanual.com/generalizedconditions/anthrax/overview-of-anthrax

21. Oscherwitz, J., Quinn, C.P., Cease, K.B. (2015). Anthrax vaccine recipients lack antibody against the loop neutralizing determinant: A protective neutralizing epitope from Bacillus anthracis protective antigen. Vaccine, 33, 20, 2342-2346

22. Quinn CP, Sabourin CL, Schiffer JM, Niemuth NA, Semenova VA, Li H, Rudge TL, Brys AM, Mittler RS, Ibegbu CC, Wrammert J, Ahmed R, Parker SD, Babcock J, Keitel W, Poland GA, Keyserling HL, El Sahly H, Jacobson RM, Marano N, Plikaytis BD, Wright JG. (2016). Humoral and Cell-Mediated Immune Responses to Alternate Booster Schedules of Anthrax Vaccine Adsorbed in Humans. Clin Vaccine Immunol., 23(4), 326-338. doi: 10.1128/CVI.00696-15.

23. Robert J. Hopkins, Nancy F. Daczkowski, Paulina E. Kaptur, Derek Muse, Eric Sheldon, Craig LaForce, Suha Sari, Thomas L. Rudge, Edward Bernton. (2013). Randomized, double-blind, placebo-controlled, safety and immunogenicity study of 4 formulations of Anthrax Vaccine Adsorbed plus CPG 7909 (AV7909) in healthy adult volunteers. Vaccine, 31, 30, 3051-3058, https://doi.org/10.1016/j.vaccine.2013.04.063.

24. Rublenko, I.O. (2018). Sybirka u tvaryn. [Anthrax in animals]. Nauk. visnyk Lviv. nats. un-tu vet. medytsyny ta biotekhnolohii im. S.H. Gzhytskoho, [Science. Bulletin of Lviv. nat. un-tu vet. of Medicine and Biotechnology S.G. Gzhytsky], 20 (83), 13-16.

25. Rublenko, I.O. (2018). Vyznachennia stupenia zalyshkovoi virulentnosti i reaktohennosti shtamu Bac. anthracis UA-07. [Determination of the degree of residual virulence and reactogenicity of strain Bac. anthracis UA - 07] Nauk.-tekhn. biuleten In-tu biolohii tvaryn i DNDKI vetpreparativ ta kormovykh dobavok [Scientific and technical Bulletin of the Institute of Animal Biology and 
DNDKI veterinary drugs and feed additives], 19 (1), 102-108.

26. Rublenko, I.O.and Skrypnyk, V.G. (2016). Features of specific immunity formation in cattle after vaccination against animals anthrax with vaccine of UA-07 "Antravak" strain". Bioresources and nature management: scientific-theoretical. Journal of NULES of Ukraine, 8. (№5-6), 67-71.

27. Sandra I. Sulsky, Rose S. Luippold, Patrick Garman, Hayley Hughes, Paul J. Amoroso, (2011). Risk of disability for US army personnel vaccinated against anthrax, 1998-2005, Vaccine, 29, 35, 6035-6041. https://doi.org/10.1016/j.vaccine.2011.06.028.

28. Skoble, J., Beaber, J.W., YiGao, Lovchik, J.A., Sower, L.E., Liu, W., Luckett, W., Peterson, J. W., Calendar, R., Portnoy, D. A., Lyons, C. R. and Dubensky, T.W. Jr. (2009).Killed but Metabolically Active Bacillus anthracis Vaccines Induce Broad and Protective Immunity against Anthrax. Infection and Immunity, 77(4), 1649-1663. DOI: 10.1128/IAI.00530-08. Available from: https://www.researchgate.net/publication/23939046_Killed_but_Metabolically_Active_Bacillus_anthracis_Vaccines_Induce_Broad_a nd_Protective_Immunity_against_Anthrax [accessed Sep 23 2020].

29. Spickler, A.R. (2017). The center of food security and public health: Disease Information. Anthrax 2017 At https://www.cfsph.iastate.edu/diseaseinfo/disease/?disease=anthrax\&lang=en

30. Tracy Pondo, Charles E. Rose, Stacey W. Martin, Wendy A. Keitel, Harry L. Keyserling, Janiine Babcock, Scott Parker, Robert M. Jacobson, Gregory A. Poland, Michael M. McNeil (2014). Evaluation of sex, race, body mass index and pre-vaccination serum progesterone levels and post-vaccination serum anti-anthrax protective immunoglobulin $\mathrm{G}$ on injection site adverse events following anthrax vaccine adsorbed (AVA) in the CDC AVA human clinical trial. Vaccine, 32, 28, 3548-3554, https://doi.org/10.1016/j.vaccine.2014.04.025.

31. William H. Catherino, Andrew Levi, Tzu-Cheg Kao, Mark P. Leondires, Jeffrey McKeeby, James H. Segars. (2005). Anthrax vaccine does not affect semen parameters, embryo quality, or pregnancy outcome in couples with a vaccinated male military service member. Fertility and Sterility, 83, 2, 480-483. https://doi.org/10.1016/j.fertnstert.2004.07.965.

32. Zhang, Y., Martin, S.W., Rose Jr., C.E., Biagini, R.E., Franzke, L.H., Smith, J.P., Sammons, D.L., Robertson, S.A, McNeil, M.M.( 2008) Evaluation of body mass index, pre-vaccination serum progesterone levels and anti-anthrax protective antigen immunoglobulin $\mathrm{G}$ on injection site adverse events following anthrax vaccination in women. Pharmacoepidemiology and Drug Safety, $17,11,1060-1067$

Yaroslav Tytukh, PhD Student, Sumy National Agrarian University (Sumy, Ukraine)

Yurii Baydevliatov, PhD in vet. science, Sumy National Agrarian University (Sumy, Ukraine)

Halyna Rebenko, PhD in vet. science, Sumy National Agrarian University (Sumy, Ukraine)

Yurii Mucienko, PhD in vet. Science, Sumy National Agrarian University (Sumy, Ukraine)

Influence of vaccination of cows against anthrax on the artificial insemination results

Fertility rate is one of the markers of the effectiveness of the livestock industry, but the successful formation and fixation of the zygote in the mucous membrane of the uterus can be hindered by various inflammatory processes. Immunological reactions of the postvaccination complex can also affect fertility.

Previous observations of the fertility status of cows on the farm indicated a significant decrease in this indicator just after vaccination against anthrax. The results of the studies presented in the article show a significant decrease in fertility. In our opinion, this is due to the immunological processes in the body of vaccinated cows that were inseminated. That is, the immune system stimulated during vaccination is not able to inhibit its work in the genital tract, and therefore prevents the attachment of the successfully formed during fertilization zygote to the uterine mucosa, which eventually ends in infertility and the onset of re-libido.

The results suggest that vaccination of animals against anthrax and especially the period of active formation of post-vaccine specific immunity reduces reproduction rates in cows: fertility rates decreased by $16.2 \%$ during the first week after vaccination and by $50 \%$ during the second compared with animals that inseminated before vaccination It was found that in cows that were inseminated during the immunological load, there was an increase in the duration of infertility - by $12.7 \%$ and $38.6 \%$, respectively. The economic loss from calves in the group of cows inseminated immediately after vaccination was 2.7 times greater, and in the group of cows inseminated in the second week after vaccination - respectively 3.5 times higher than in cows inseminated before vaccination. Losses from milk shortage in these groups increased by $7.6 \%$ and $38.4 \%$, respectively.

Key words: fertility rate, artificial insemination, vaccination against anthrax, economic loss

Дата надходження до редакції: 20.11.2020 р. 